\title{
Disarmament, Development and Security
}

Shridath S. Ramphal

In April 1985 an International Symposium 'Survival in the Nuclear Age', sponsored jointly by the Third World Foundation and Parliamentarians for World Order and chaired by Willy Brandt, reached the conclusion that:

There exists a dynamic triangular relationship between disarmament, development and security ... The failure to bring the arms race under control which led to deepening confrontation and distrust, and the preoccupation with security has had adverse consequences not only for East-West detente, but also for North-South cooperation.

Because disarmament is not occurring, not one dollar or rouble of the massive funds at present devoted to armaments is being converted to development. Accelerating world armaments expenditures are now running at about $\$ 1,000$ bn annually, some four-fifths of it in the US, the Soviet Union and their allies, with 'Star Wars' research threatening a further dramatic increase in both expenditure and East-West tensions. Spending at this level for these purposes is a violation of morality and civilisation at a time when human needs have been glaringly highlighted by famine in Africa and a virtual halt to development in many Third World countries.

The problem, however, is not primarily one of getting the disarmament-development relationship on to agendas at the UN and elsewhere. At the UN, disarmament has been on the agenda since its inception, with very early recognition of its potential for furthering development. The disarmamentdevelopment relationship was an important element in the programme for disarmament agreed by consensus at the First Special Session on Disarmament in 1978 and contained in the Final Document. Proposals for a development fund to be taken out of military expenditure were made as far back as 1955; disarmament-development is now regularly considered by the General Assembly; and this year the Assembly has even agreed to set up a Preparatory Committee for a Disarmament and Development Conference though at the price of all reference to a possible fund being omitted from the initiating resolution.

Cynicism is inevitable when years of talking on disarmament-development produce no visible results. The high points of East-West agreement in the period of detente have not been built on and are receding into history. Efforts inside and outside the UN to stimulate real progress on disarmament and disarmamentdevelopment have fared badly. The enthusiasm of the mass disarmament rally in New York during the Second Special Session on Disarmament contrasted sharply with the minimal results achieved inside the UN by the official discussions. And there have been defaults in areas where agreements have been reached. When the Nuclear Non-Proliferation Treaty is reviewed this September in Geneva, non-nuclear countries will be reminding the three nuclear signatories of their failure to make progress on nuclear disarmament as the Treaty enjoined them to do.

Though so little has been achieved at national or international governmental levels, a discernible impact was made on public opinion by the Brandt and Palme Commissions, both of which dealt with the link between disarmament and development as well as with these issues separately. The Brandt Report called for deeper understanding of security going beyond its military aspects and for a strengthened role for the UN in a system of international security which might free resources for development. It also identified a tax on the arms trade as one possible component in a system of international taxation for development. Examining these issues in greater detail, the Palme Commission in 1982 argued that, far from harming economies, reductions in military spending would in fact increase the prospects for resumed growth in the world economy. In this, it was in tune with the findings of the UN Governmental Expert Group chaired by Inga Thorsson of Sweden. This Group argued that since disarmament was an essential element in sustained,

WDS Bullerin. 1985. vol 16 no 4. Institute of Development Studies. Sussex 
non-inflationary and equitable growth, a direct connection existed between disarmament and development. Particularly in relation to small developing countries, the Palme Report called as well for a new emphasis on collective security.

Both the Thorsson and Palme Reports were inscribed on UN agendas, but the context in which they were received was not propitious. In late 1983, resumed US-Soviet disarmament negotiations in Geneva broke down. Against this gloomy background, the Brandt and Palme Commissions held a joint meeting in Rome in January 1984. In their communique, they pointed to some seriously worrying issues: the accelerating arms race; deteriorating international security; several wars continuing unabated in the Third World; anxiety among small states which were especially vulnerable in the absence of common security arrangements and respect for international law. They also noted that the economic situation was far worse than when the Brandt Report was originally prepared, with industrial economies in recession and facing the highest unemployment levels in the post-war period, and many developing countries experiencing falling living standards and unsustainable debt burdens due in significant measure to the international climate of low growth and high interest rates.

The Commissions recognised the close relationship between security and development, and in the process by which economic distress caused instability in Third World countries which in turn could draw in outside powers with the ultimate risk of nuclear war. They stressed, in words which are worth recalling, that national security must be founded on recognition of common interests and respect for common institutions, foremost among which were the United Nations and associated regional cooperation and security arrangements. And they drew attention to the resources which even partial disarmament would release for development and peace-keeping efforts, pointing out that only 0.1 per cent of worldwide military spending would treble the UN's peacekeeping resources. In conclusion, the two Commissions saw the need for a new world order, in which people could live without fear and hunger, and where vast materials and intellectual resources were not directed to the production of new weapons of destruction, and affirmed the need to move forward out of crisis to common prosperity and common security.

It was a measure of the bleak spirit of January 1984 that this prescription met with little apparent attention in the world's press and the international community. One should not be discouraged, however, at the lack of immediate reaction. The wheels of disarmament and development grind slow; but events will not always wait. For those tens of thousands in Africa who did starve, the conversion of funds to development is no longer of any relevance. There have, however, been some moves in the right direction: the restarted Geneva talks; hints of a possibly less grudging attitude to multilateralism on the part of the US; tentative talks in the Security Council on strengthening its international security role; and Sweden (despite its own substantial arms trade) has responded to the UN call for national studies on the economic effects of the conversion of armaments industries to peaceful uses. Above all, new leadership in the Soviet Union has created an opportunity not only for a fresh effort to improve East-West relations but for the Soviet Union to participate more fully in the world community and make a more substantial contribution to development, particularly through the international institutions, consistent with its world role.

While disarmament continues to depend on talks between the superpowers, the non-nuclear countries should make their vital concerns known. Quite apart from the fact that a nuclear winter will eclipse the tropical sun, the contribution disarmament could make to development also requires that the participants be made aware of the Third World's close interest in the outcome of disarmament negotiations. The central importance of East-West talks should be balanced by the Commonwealth perception that there are many centres and no peripheries. The nuclear winter will not distinguish between participants and victims, any more than the debris of ruined Maginot Lines in space can be programmed to pollute the environment of the superpowers alone.

It is vital, therefore, that alternative voices are heard on disarmament. The Commonwealth is one of these, and the time is right to repeat a Commonwealth message to the superpowers. Meeting in India two years ago, Commonwealth leaders in their Goa Declaration on International Security, issued a call to both the Soviet Union and the United States to resume dialogue and summon up the political vision of a world in which their nations can live in peace. They called, too, for a halt to the arms race, a release of resources from disarmament to development, and a strengthening of the UN to enable it to fulfil its Charter obligations. They expressed special concern at the vulnerability and insecurity of the world's small states, many Commonwealth members among them, and initiated an urgent study of these countries' needs (to be presented to the Commonwealth's October summit in the Bahamas). During the New Delhi meeting there was a particularly lively discussion of the linkage between a non-proliferation regime in which nuclear powers fulfilled NPT obligations and a decision to devote to development a measure of the resources saved. 
There are other voices too: the Five Continent Peace Initiative; the Latin American 'Contadora' group; the recent international symposium 'Survival in the Nuclear Age', which brought together eminent persons from the worlds of science and politics and from East and West, North and South; and the South Pacific Forum. The Forum's consensus against nuclear testing and dumping in the Pacific Ocean is particularly relevant. It reflects the need for security felt by the smallest countries. Their sense of insecurity stems from military, economic and political vulnerability. Because of their smallness, effective defence is prohibitively expensive and also potentially destabilising because it could create dangerous centres of military power within these countries.

While the behaviour of the superpowers and the lack of collective security are the main factors behind extensive arms spending, many developing countries have themselves lavished scarce resources on arms. The impact is mainly negative. Third World arms spending is usually characterised by a high import content, involving foreign exchange and external debt, and a low level of technology; only a few countries such as India and Brazil have developed an impressive domestic technology. Developing countries understandably insist that they cannot neglect their own security while the superpowers escalate the arms race unchecked, and policies of destabilisation such as those pursued by South Africa in relation to neighbouring countries reinforce their case. Nevertheless, it is worth examining ways in which developing countries could cooperate with the international community in cutting arms spending to benefit their own development. In this respect, the question of collective security, especially for the smallest countries, assumes special importance. While developing countries must find new ways of exercising restraint at the arms bazaar, international financial institutions, and even national ECGD agencies should also orient their policies towards discouraging the arms trade rather than the reverse.

It is essential that these and other practical policy considerations are addressed within the disarmament process. This need may have been at least tacitly recognised by governments through their decision last year to convene a full-scale UN Conference to review the relationship between disarmament and development in all its aspects and dimensions with a view to reaching appropriate conclusions. Although that decision, and the way it was worded in the General Assembly's enabling resolution, undoubtedly masks some deep-seated differences of attitude, it was nevertheless taken without a dissenting note. It is to be hoped that this represents a definite commitment on the part of all governments to allow the crucial disarmament-development relationship to occupy a central position in the international debate on all disarmament-related issues.

In calling upon governments to plan for and prepare a process of conversion of resources from military to constructive civilian use, the symposium on 'Survival in the Nuclear Age' urged the major nuclear powers to agree on rules which make World War III impossible. Asserting that it is unacceptable and terrifying that the people of the world must depend on their right to live on a small group of people in one or two capitals, the Symposium issued a call for the rapid initiation and implementation of a minimum four-point programme on disarmament to include the following measures:

- an agreement to prevent the militarisation of and the extension of the arms race to outer space;

- the immediate cessation of all tests of nuclear weapons and the prompt conclusion of a comprehensive test ban treaty;

- a mutual and verifiable freeze on the testing, production, and deployment of nuclear weapons and their delivery systems;

- a declaration by those nuclear weapons states that have not done so, not to be the first to use nuclear weapons.

As we look towards the UN Conference on Disarmament and Development, it is essential to remember that, while the main burden of reaching agreement on disarmament rests with the two superpowers and their allies, vitally important roles exist for all countries and all people, including those of the developing world. Coalitions of middle-countries and the collective voice of most of the world's people can encourage the superpowers to end the threat of an all-destroying world conflict and to enlarge the prospects for both development and security. Those coalitions need to be developed and those voices raised now if we are to ensure that the opportunity provided by the Conference is not lost. This is a powerful conjuncture that can rekindle the hopes of San Francisco by releasing the pent-up dynamic of disarmament, development and security. 